\title{
Water use and onion crop production in no-tillage and conventional cropping systems
}

\author{
Waldir Aparecido Marouelli ${ }^{1}$; Rômulo P Abdalla²; Nuno R Madeira ${ }^{1}$; Henoque R da Silva'; Aureo S de \\ Oliveira $^{3}$ \\ ${ }^{1}$ Embrapa Hortaliças, C. Postal 218, 70351-970 Brasília-DF; 2 ${ }^{2}$ aculdade da Terra de Brasília, Quadra 203, Área Especial, Lote 32, 72610- \\ 300 Recanto das Emas-DF; ${ }^{3}$ Universidade Federal do Recôncavo da Bahia - Núcleo de Engenharia de Água e Solo, C. Postal 28, 44380- \\ 000 Cruz das Almas-BA; waldir@cnph.embrapa.br; romulo@cnph.embrapa.br; nuno@cnph.embrapa.br; henoque@cnph.embrapa.br; \\ aureo@ufrb.edu.br
}

\begin{abstract}
The objective of the present study was to evaluate the effects of crop residue covers $\left(0.0 ; 4.5 ; 9.0 ; 13.5 \mathrm{t} \mathrm{ha}^{-1}\right.$ millet dry matter) on water use and production of onion cultivated in no-tillage planting system (NT) as compared to conventional tillage system (CT). The study was carried out at Embrapa Hortaliças, Brazil, under the typical Savanna biome. Irrigations were performed using a sprinkle irrigation system when soil-water tension reached between 25 and $30 \mathrm{kPa}$. The experimental design was randomized blocks with three replications. Total net water depth applied to NT treatment was 19\% smaller than the CT treatment, however, water savings increased to $30 \%$ for the first 30 days following seedlings transplant. Crop biomass, bulb size and yield, and rate of rotten bulbs were not significantly affected by treatments. The water productivity index increased linearly with increasing crop residue in NT conditions. Water productivity index of NT treatments with crop residue was on average $30 \%$ higher than that in the CT system $\left(8.13 \mathrm{~kg} \mathrm{~m}^{-3}\right)$.
\end{abstract}

Keywords: Allium cepa L., reduced tillage, water use efficiency, irrigation, Savannah.

\section{RESUMO}

Uso de água e produção de cebola em sistemas de plantio direto e convencional

O objetivo do presente estudo foi avaliar o efeito do nível de palhada no solo $\left(0,0 ; 4,5 ; 9,0 ; 13,5 \mathrm{tha}^{-1}\right.$ de matéria seca de milheto) em sistema de plantio direto (PD) sobre o uso de água e produção de cebola, tendo como controle o sistema de plantio convencional (PC). $\mathrm{O}$ ensaio foi conduzido na Embrapa Hortaliças, em região típica do bioma Cerrado. As irrigações foram realizadas por aspersão a todo o momento que a tensão de água no solo atingiu entre 25 e $30 \mathrm{kPa}$. O delineamento experimental foi blocos ao acaso com três repetições. A lâmina de água aplicada em PD foi de até 19\% menor que no tratamento PC durante o ciclo da cultura, sendo que durante os primeiros 30 dias do ciclo após o transplante das mudas a economia chegou a $30 \%$. O desenvolvimento de plantas, o tamanho e o rendimento de bulbos, e a taxa de bulbos podres não foram afetados significativamente pelos tratamentos. $\mathrm{O}$ índice de produtividade da água no PD aumentou linearmente com o aumento do nível de palhada, sendo que o índice nos tratamentos PD com palhada foi em média 30\% maior que em PC $\left(8,13 \mathrm{~kg} \mathrm{~m}^{-3}\right)$.

Palavras-chave: Allium cepa L., cultivo mínimo, eficiência do uso de água, irrigação, Cerrado.

(Recebido para publicação em 23 de outubro de 2008; aceito em 11 de fevereiro de 2010)

(Received on October 23, 2008; accepted on February 11, 2010)

$\mathrm{T}$ The onion (Allium cepa L.) is the third vegetable crop of economical importance in Brazil with a total harvested area of 62,750 hectares and a total production of 1.3 million tons (Embrapa Hortaliças, 2008). Generally speaking, the use of conventional tillage system (CT) for onion production predominates in Brazil, however, due to its benefits the no-tillage system (NT) has been adopted in some production areas of Brazil, mainly, in Santa Catarina, São Paulo, Minas Gerais and Goiás States (Madeira \& Oliveira, 2005).

According to Gilley et al. (1990) and Derpsch et al. (1991), the advantages of NT include reduced machinery traffic, soil structure improvement, increasing infiltration and soil-water retention, water loss reduction by evaporation and runoff, superior crop root system development, improved control of weeds, erosion processes reduction, and increased water use efficiency.

Field research on the use of NT systems for vegetable production is scarce and management practices that include irrigation frequency and amount of applied water are, in general, the same as recommended for CT. As a result of the inadequate crop water management it is common to notice higher intensity of diseases in NT which reduces crop yield and harvest quality affecting farm revenue reducing loss of the known benefits obtained with this planting system.

Water conservation with the NT systems mainly occurs due to the crop residues left on soil surface which act as a physical barrier against water evaporation (Derpsch et al., 1991).

During the early development stage, onion plants only cover a fraction of the soil surface, therefore, soil evaporation accounts for most of the crop evapotranspiration. Then, plant water use during this stage is less mainly for crops with lower capability of soil coverage (Stone \& Moreira, 2000). On the other hand, the transpiration process becomes predominant as plants grow and cover larger fractions of soil surface. According to Allen et al. (1998), crop evapotranspiration can be reduced in as much as $25 \%$ during the early stage and between 5 and $10 \%$ 
during the maximum development stage for a condition of $50 \%$ of surface soil coverage with crop residues. Landers (1995) reported water conservation in NT varying between 10 and $20 \%$ in oxysols of the Central Brazil.

The objective of the present study was to quantify both irrigation water use and production of onion when cultivated in NT systems with different levels of crop residue covers as compared to $\mathrm{CT}$, in a typical condition of climate and soil in the Brazilian Savannahs.

\section{MATERIAL AND METHODS}

Field plots were set up in the Embrapa Hortaliça's experimental station, Brasília, Brazil, during the dry season of 2007 in the area for the management of NT. The soil was a typical dystrophic Red Oxysol of Savannah with clay texture and water retention of $1.2 \mathrm{~mm}$ $\mathrm{cm}^{-1}$ (Embrapa, 2006). According to the Köppen classification, the climate is a Cwa, i.e., temperate humid with dry winter and hot summer.

The experimental design was randomized blocks with five treatments and three replications. The treatments consisted of four rates of millet crop residue covering the soil $(0.0 ; 4.5 ; 9.0$; $13.5 \mathrm{t} \mathrm{ha}^{-1}$ of dry mass) in NT and one control treatment without millet residue (CT). In order to build up the soil cover, the millet crop was cultivated at different sowing densities in the plots. At harvest and following millet dry mass plots sampling a final adjustment was done by adding or subtracting crop residue to match each treatment level before transplanting of onion seedlings. In all $\mathrm{NT}_{0.0 t / h a}$ plots the millet crop was not cultivated, however, a minimum of natural vegetation was kept while millet was grown in the other plots. Relatively speaking, the NT crop residue rates proportionated a soil cover of about 0 , 30,60 and $90 \%$, respectively, according to visual evaluation by three judges.

A population of onion-type "Baia Periforme" (CNPH 6400) was cultivated, belonging to the Breeding Program of Embrapa, which is ending development. Seedlings were grown in soil beds inside a greenhouse and transplanted to plots by middle June in a $0.25-\mathrm{m} \mathrm{x}$ 0.07-m spacing, providing a stand of 476 thousand plants per hectare. The total area of each plot was $38.4 \mathrm{~m}^{2}$ (6.4 x 6.0 $\mathrm{m})$ from which $12.8 \mathrm{~m}^{2}$ were harvested for evaluation of production variables.

In all NT plots the seedlings were transplanted in small furrows $(0.05 \mathrm{~m}$ wide, and $0.08 \mathrm{~m}$ deep) mechanically opened. On the other hand, the CT treatment consisted of the mechanical operations of plowing, grading, furrowing, fertilization and transplant. To avoid soil compaction in NT plots, a 4.0-m buffer surrounding CT plot was left. Preplanting fertilization was done according to soil chemical analysis with application of $1,000 \mathrm{~kg} \mathrm{ha}^{-1}$ of the formula 04-30-16, and for side dressing fertilization $600 \mathrm{~kg} \mathrm{ha}^{-1}$ of the formula 20-0-20 split in three applications of 200 $\mathrm{kg} \mathrm{ha}^{-1}$ at 20,40, and 60 days following seedlings transplant was applied. The remaining cultural practices followed the recommendations by Oliveira \& Boiteux (2008).

A microsprinkler irrigation system was used in order to decrease plot size. The emitters were set up at a 2.0-m x 2.0-m spacing with the application rate of $16.3 \mathrm{~mm} \mathrm{~h}^{-1}$ which resulted in full surface wetting cover. The Christiansen coefficient ranged between $80 \%$ and $90 \%$ as a function of wind conditions.

Irrigation events followed a schedule based on soil-water tension between 25 and $30 \mathrm{kPa}$ at crop $50 \%$ effective rooting depth (Marouelli et al., 2005), i.e., 0.08 $\mathrm{m}$ from transplant to beginning of bulb forming, and $0.15 \mathrm{~m}$ afterward. The soil water tension was measured using tensiometers installed one per plot. The depth of applied water in each irrigation event was sufficient to bring soil moisture content to field capacity $(6 \mathrm{kPa})$ at the onion effective rooting profile. The effective root depth was considered as the profile depth with $80 \%$ of onion roots concentration. The effective root depth was visually evaluated by opening a trench perpendicular to crop rows, in the buffer surrounding of CT plots. The crop irrigation events ceased when about $50 \%$ of leaves senesced and the tops have fallen naturally (Marouelli et al., 2005).

The crop was harvested 111 days from seedlings transplant. The following crop variables were evaluated: number and average weight of non-marketable bulbs (<35 mm); number and average weight of marketable bulbs (class 2: diameter from 35 - $50 \mathrm{~mm}$, class 3: 50$70 \mathrm{~mm}$, class 4: 70-90 mm, and class 5: $>90 \mathrm{~mm}$ ); and canopy biomass (13\% wet basis). The crop production variables were evaluated after bulb curing 30 days after harvest. To access post-harvest conservation of bulbs, the percentage of number of rotten bulbs caused by bacteria and fungus at 30 and 60 days after harvest were evaluated.

The water productivity index was derived from bulb yield and total depth of applied water which is given by the ratio of marketable bulb yield to the volume of water effectively applied through irrigation per unit area (Jensen, 2007). The water applied was determined based on the average depth from four pluviometers diagonally installed above the crop canopy in one plot at each treatment.

The ANOVA was applied to the data and the variables affected by the different crop residue covers in NT were further analyzed by a linear regression using orthogonal polynomials. The multiple comparison Dunnett " $\mathrm{t}$ " test was used to confront CT to NT treatment averages at 5\% maximum level of significance.

\section{RESULTS AND DISCUSSION}

The total rainfall occurred during the test period was $4 \mathrm{~mm}$, which probably had no effect on the results. Throughout the entire crop cycle irrigation events varied between 31 and 39 for NT, and for CT totaled 39 events (Table 1). Correspondently, the total depth of water applied during crop cycle ranged between 525 and $625 \mathrm{~mm}$ for NT, and totaled $646 \mathrm{~mm}$ for CT (Table 1). Hence, compared to CT the water savings with NT were as much as $19 \%$. Stone \& Moreira (2000) and Marouelli et al. (2006) also verified significant water savings in studies with soil surface coverage with crop residues. Landers (1995) and Allen et al. (1998) reported reduction in the average water use of $15 \%$ in NT systems of different crops.

The current reduction in water 
Table 1. Number of irrigations and water depth effectively applied to onion cultivated in no-tillage (NT), with levels of crop residue cover up to $13.5 \mathrm{t} \mathrm{ha}^{-1}$, and conventional tillage systems (CT) during the first 30 days after seedlings transplant, throughout crop cycle, and during the last 30 days of irrigation, and water savings in NT treatments compared to CT (quantidade total de irrigações e lâmina de água efetivamente aplicada na cultura de cebola em sistemas de plantio direto (NT), com níveis de palhada até 13,5 t ha $^{-1}$, e de plantio convencional (CT) durante os primeiros 30 dias após o transplante de mudas, ao longo do ciclo e durante os últimos 30 dias de irrigação, e economia do uso de água nos tratamentos NT em relação ao CT). Brasília, Embrapa Hortaliças, 2007.

\begin{tabular}{|c|c|c|c|c|c|c|c|}
\hline \multirow[b]{2}{*}{ Treatment } & \multirow{2}{*}{$\begin{array}{c}\text { No. of } \\
\text { irrigations }\end{array}$} & \multicolumn{2}{|c|}{ First 30 days } & \multicolumn{2}{|c|}{ Last 30 days } & \multicolumn{2}{|c|}{ Entire cycle (111 days) } \\
\hline & & $\begin{array}{c}\text { Water } \\
\text { depth }(\mathbf{m m})\end{array}$ & $\begin{array}{c}\text { Water } \\
\text { depth }(\mathrm{mm})\end{array}$ & $\begin{array}{c}\text { Water } \\
\text { savings (\%) }\end{array}$ & $\begin{array}{c}\text { Water } \\
\text { savings (\%) }\end{array}$ & $\begin{array}{c}\text { Water } \\
\text { depth }(\mathrm{mm})\end{array}$ & $\begin{array}{c}\text { Water } \\
\text { savings (\%) }\end{array}$ \\
\hline $\mathrm{NT}_{0.0 \text { tha }}$ & 39 & 117 & 305 & 2 & 3 & 625 & 3 \\
\hline $\mathrm{NT}_{4.5}$ tha & 35 & 97 & 295 & 5 & 20 & 564 & 13 \\
\hline $\mathrm{NT}_{9.0 \text { tha }}$ & 33 & 91 & 289 & 7 & 25 & 540 & 16 \\
\hline $\mathrm{NT}_{13.5 \text { tha }}$ & 31 & 85 & 281 & 10 & 30 & 525 & 19 \\
\hline $\mathrm{CT}^{13.5 \text { tha }}$ & 39 & 121 & 312 & -- & -- & 646 & -- \\
\hline
\end{tabular}

applied with the NT system was twice higher than that observed in studies by Marouelli et al. (2006) with processing tomatoes under similar soil and climate conditions. Considering both crop soil coverage capabilities, the water losses by evaporation of onion in CT are proportionally higher than that of processing tomatoes cultivated in NT (Allen et al., 1998).

The water savings in NT are due to effect of the soil coverage which works as a barrier preventing water evaporation from soil surface. According to Stone \& Moreira (2000), the crop residue cover initially acts in the soil-water evaporation process by reducing the

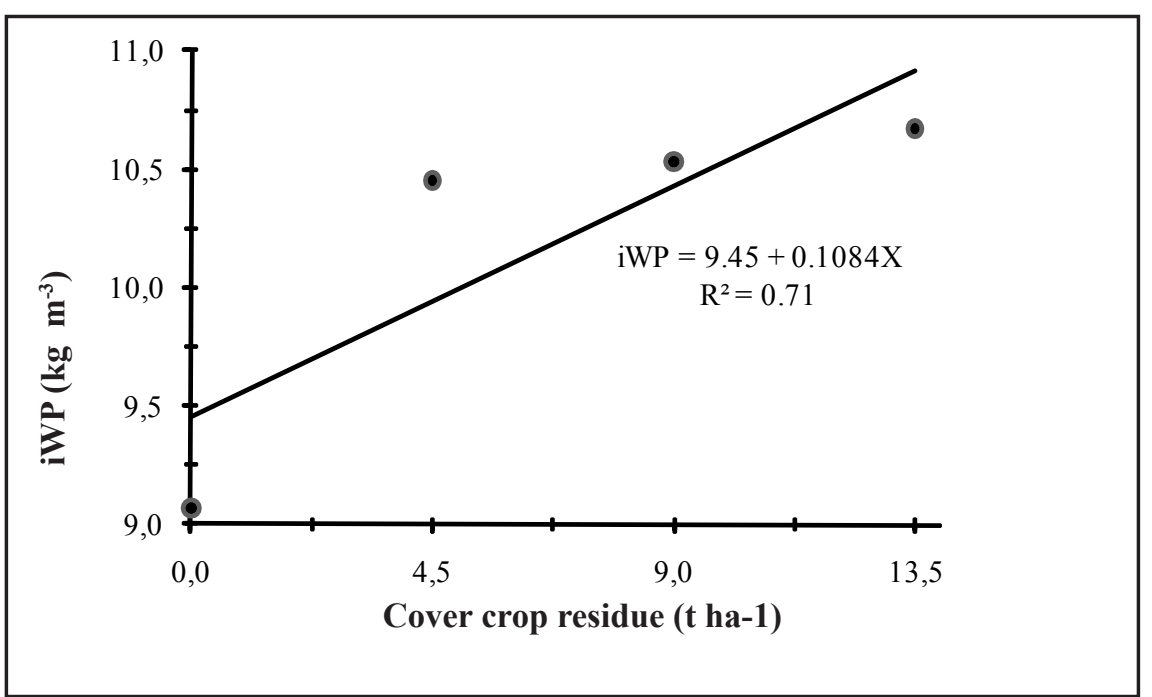

Figure 1. Water productivity index (iWP) for onion crop according to the amount of crop residue covering the soil in no-tillage system (função de resposta para índice de produtividade da água (iWP) para a cultura de cebola, conforme a quantidade de palhada em sistema de plantio direto). Brasília, Embrapa Hortaliças, 2007. daily evaporation rate due to higher solar radiation reflection, and consequently, the crop evapotranspiration.

If considered only the first 30 days after seedling transplant, the depth of water required for NT treatments with residue covers was reduced between 20 and $30 \%$ as compared to CT. On the other hand, water savings in NT treatments were smaller for the last 30 days of irrigation ranging between 5 and $10 \%$ as compared to CT (Table 1). The most water savings in NT treatments during the onion initial development stage were due to the small fraction of soil covered by plants and to the fact surface evaporation accounts for

the most part of irrigation demand. At the end of crop cycle, when the plants cover most of the soil surface, transpiration becomes the major process in transferring water; hence, water saving is attenuated (Derpsch et al., 1991; Stone \& Moreira, 2000).

Neither NT nor CT treatments affected significantly $(\mathrm{p}>0.05)$ the crop biomass production (in average 2.14 $\mathrm{t} \mathrm{ha}^{-1}$ ), total number of bulbs per unit

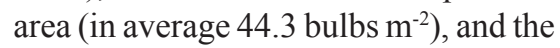
weight of marketable bulbs (in average $137.4 \mathrm{~g}$ ). Consequently, bulb yields of class 2 (in average $2.4 \mathrm{t} \mathrm{ha}^{-1}$ ), class 3 (in average $33.7 \mathrm{t} \mathrm{ha}^{-1}$ ), and class 4 (in average $20.1 \mathrm{t} \mathrm{ha}^{-1}$ ), and marketable bulbs (in average $56.2 \mathrm{t} \mathrm{ha}^{-1}$ ) were not affected by the treatments. The bulb yield of class 5 was very small.

Apparently, the results of bulb yields reported above differ from those reported by Madeira \& Oliveira (2005), who showed significant differences in onion bulb yield for both NT and CT. The possible lack of yield differences between both NT and CT treatments under the current study was due to individualized irrigation water management by treatment, with irrigations carried out at the right time (soil-water tension $25-30 \mathrm{kPa}$ ) and in adequate amount to meet the crop water needs, i.e., no excess or shortage. On the other hand, Madeira \& Oliveira (2005) applied uniform irrigation events for both NT and CT planting systems, which may have promoted conditions of excess or shortage of water for either system, hence affecting bulb yield. 
Similarly to the yield component variables, NT and CT treatments did not significantly affect the postharvest conservation of bulbs as evaluated by the number of rotten bulbs at 30 days (in average $3.4 \%$ ) and 60 days (in average $12.4 \%$ ) of storage. According to Marouelli et al. (2005), excess irrigation affects onion bulb storage conservation, in special during maturation crop development stage. In the present study, however, despite of the total depth of irrigation water have varied between treatments, the conditions of soil moisture that the plants were submitted in all treatments were similar. Therefore, no onion bulb storage conservation variation was expected as a function of treatments.

The water productivity index was significantly affected by treatments $(\mathrm{p}<0.05)$. By the Dunnett test $(\mathrm{p}<0.05)$, the water index of the control treatment CT $\left(8.13 \mathrm{~kg} \mathrm{~m}^{-3}\right)$ did not differ from the $\mathrm{NT}_{0.0 t / h a}$, but was statistically less than NT treatments with crop residues.

The water productivity index increased linearly with increasing level of crop residues in NT system, ranging from 9.07 to $10.67 \mathrm{~kg} \mathrm{~m}^{-3}$ (Figure 1) showing no significance $(p<0.05)$ for polynomial coefficients of second and third order. Based on the adjusted regression equation an increase of 1.08 $\mathrm{kg}$ of onion per $10 \mathrm{~m}^{3}$ of water was observed for each ton of crop residue spread over the soil surface.

The cultivation of onion crop in NT with crop residue levels between 4.5 and $13.5 \mathrm{t} \mathrm{ha}^{-1}$ averaged $30 \%$ more water use efficient than CT with similar bulb yield. This finding agrees with Stone \& Moreira (2000) and Marouelli et al. (2006) studies who found that besides reducing soil evaporation losses, the NT system is also more efficient in water use by the crop.

In summary, plant growth, bulb production and postharvest conservation in NT treatments did not differ from that observed in control treatment CT, however, the higher the crop residue level the lower the irrigation water demand. Therefore, the results allow inferring that surface soil coverage with crop residues endorses effective reduction in onion crop water use with maintenance of high levels of bulb yield and a considerable increase in the water productivity index for the case irrigations are applied at both right time and amount.

\section{ACKNOWLEDGEMENTS}

Thanks to Dr. Valter Rodrigues Oliveira, researcher responsible for the Onion Breeding Program of Embrapa, for providing seeds from advanced onion population, and to $\mathrm{CNPq}$, for partial funding of this research.

\section{REFERENCES}

ALLEN RG; PEREIRA LS; RAES D; SMITH M. 1998. Crop evapotranspiration: guidelines for computing crop water requirements. Rome: FAO. 300p.

DERPSCH R; ROTH CH; SIDIRAS N; KOPKE U; KRAUSE R; BLANKEN J. 1991. Controle da erosão no Paraná, Brasil: sistemas de cobertura do solo, plantio direto e preparo conservacionista do solo. Eschborn: Deutsche
Gesellschaft f'ur Technische Zusammenarbeit (GTZ) GmbH. 272p. (Sonderpublikation der GTZ, 245).

EMBRAPA HORTALIÇAS. 2008, 17 de abril. Situação da cebola no Brasil e regiões, 2007. Disponível em: http://www.cnph.embrapa. br/paginas/hortalicas_em_numeros/situacao_ cebola_brasil_regioes_2007.pdf.

EMBRAPA. 2006. Sistema brasileiro de classificação de solos. 2.ed. Rio de Janeiro: Embrapa Solos. 306 p.

GILLEY JR; HACKBART CA; STETSON LE; FEYEN J. 1990. Energy management. In: HOFFMAN GJ; HOWELL TA; SOLOMON KH. (eds.). Management of farm irrigation systems. St. Joseph: ASAE. p. 719-746.

JENSEN ME. 2007. Sustainable and productive irrigated agriculture. In: HOFFMAN GJ; EVANS RG; JENSEN ME; MARTIN DL; ELLIOTT RL. (eds). Design and operation of farm irrigation systems. 2.ed. St. Joseph: ASABE. p. 33-56.

LANDERS JN. (ed.). 1995. Fascículo de experiências de plantio direto no cerrado. Goiânia: Associação de Plantio Direto no Cerrado. 261p.

MADEIRA NR; OLIVEIRA VR. 2005. Avaliação de plantas de cobertura na formação de palhada e cultivares no plantio direto de cebola. Horticultura Brasileira 23: 389. Suplemento.

MAROUELLI WA; COSTA EL; SILVA HR. 2005. Irrigação da cultura de cebola. Brasília: Embrapa Hortaliças. 17 p. (Embrapa Hortaliças. Circular Técnica, 37).

MAROUELLI WA; SILVA HR; MADEIRA NR. 2006. Uso de água e produção de tomateiro para processamento em sistema de plantio direto com palhada. Pesquisa Agropecuária Brasileira 41: 1399-1404.

OLIVEIRA VR; BOITEUX LS. (eds). 2008, 03 de abril. Cultivo da cebola. Disponível em: http:/www.cnph.embrapa.br/paginas/ sistemas_producao/cultivo_da_cebola.htm.

STONE LF; MOREIRA JAA. 2000. Efeitos de sistemas de preparo do solo no uso da água e na produtividade do feijoeiro. Pesquisa Agropecuária Brasileira 35: 835-841. 